\title{
Fatal Haemolytic-uraemic Syndrome in Two Sibs
}

\author{
PETER P. ANTHONY and ANTHONY B. KAPLAN \\ From the Departments of Histopathology and Paediatrics, Central Middlesex Hospital, London N.W.10
}

The first clear account of this syndrome was published by Gasser et al. (1955), who gave it its name. Since then some 200 cases have been reported from all parts of the world (Piel and Phibbs, 1966). The syndrome is characterized by non-immune, Coombs negative, haemolytic anaemia, with bizarre red cells, variable thrombocytopenia, and acute renal failure. At necropsy the main findings are necrotizing glomerular lesions with fibrinous capillary thromboses.

The aetiology remains obscure, though the occurrence of a viral-like, prodromal illness (Gianantonio et al., 1964) and a tendency for cases to occur in groups (McLean, Jones, and Sutherland, 1966) have both been noted. Despite intensive research, however, no viral, bacterial, or toxic agent has yet been convincingly demonstrated.

Campbell and Carré (1965) were the first to report a familial incidence in a pair of monozygotic twins who were also affected by idiopathic hyperlipaemia. Recently Hagge et al. (1967) added two cases in sibs without hyperlipaemia. The possibility, therefore, that a genetic factor may be involved has prompted us to record two further cases in sibs, neither of whom showed evidence of hyperlipaemia and in both of whom the syndrome developed in the neonatal period.

\section{Case Reports}

The mother was 21 years of age when her first child (Case 1) was born in January 1962. In the same year she became pregnant again, but an antepartum haemorrhage at the 33rd week resulted in stillbirth. At necropsy no abnormality was found other than evidence of intrauterine asphyxia. Her third pregnancy ended at term in July 1964, with the delivery of a healthy infant who remains alive and well. The fourth child (Case 2) was born in September 1965. Both parents are of Irish descent and are unrelated. The mother's blood group is A Rhesus positive, and the Wassermann reaction was negative in all her pregnancies. Atypical blood group antibodies were never demonstrated. The past, personal, and family histories are non-contributory.

Received October 18, 1967.
Case 1. The first child, a male infant weighing 2030 g., was born at term in January 1962, after an uneventful pregnancy. Labour and delivery were uncomplicated. Blood group, $\mathrm{O} R \mathrm{Rh}$ positive. During the first week of life the infant had three small haematemeses, but, despite this, he remained well and $\mathrm{Hb}$ concentration, bleeding, and clotting times were normal. Progress was normal until the 17th day of life when pustules were noted on the abdomen from which Staphylococcus pyogenes was isolated. On the 25th day he began to vomit and the spleen became palpable. Pallor was noted, which became progressively more marked, and 10 days later blood examination showed $\mathrm{Hb} 5 \cdot 2$ g./100 ml., with marked anisocytosis of red cells. He was transfused but anaemia persisted and purpuric spots now appeared on the feet. $\mathrm{Hb}$ had dropped further to $4.4 \mathrm{~g} . / 100 \mathrm{ml}$. and the platelet count was $10,000 /$ cu.mm. Urine examination showed protein +++ , red cells +++ , and leucocytes + . He was given a further transfusion but cardiac failure developed and he died on the 40th day of life.

Case 2. The fourth child, a male infant weighing 2050 g., was born at term in September 1965, after a normal pregnancy. Breech presentation with prolapse of the cord necessitated delivery by caesarean section. Blood group, $\mathrm{O} R \mathrm{R}$ positive. The infant was well until the 14th day, when a small rectal bleed occurred, unaccompanied by diarrhoea. Anaemia slowly became apparent, and 3 days later laboratory tests showed: $\mathrm{Hb}$ $7 \cdot 2$ g. $/ 100 \mathrm{ml}$., reticulocytes $4 \%$, platelet count $116,000 /$ cu.mm., bleeding and clotting times normal. Coombs test was negative, but marked anisocytosis of red cells was noted in the peripheral blood, with fragmentation and frequent bizarre shapes. The urine showed protein ++ , with red cells + , and the blood urea was $85 \mathrm{mg} . / 100 \mathrm{ml}$. He was transfused but remained pale and breathless and the spleen became palpable. By the $21 \mathrm{st}$ day $\mathrm{Hb}$ had fallen to $4.6 \mathrm{~g} . / 100 \mathrm{ml}$., and the blood urea rose to $300 \mathrm{mg}$. $/ 100 \mathrm{ml}$. He continued to deteriorate and died on the 23 rd day of life.

\section{Pathology}

Necropsy was performed in both cases and the findings were similar. The kidneys were swollen, with tense capsules and cortical mottling. Histology showed glomeruli of variable size, some being small and ischaemic, others large, swollen, and haemorrhagic. Hyaline, 


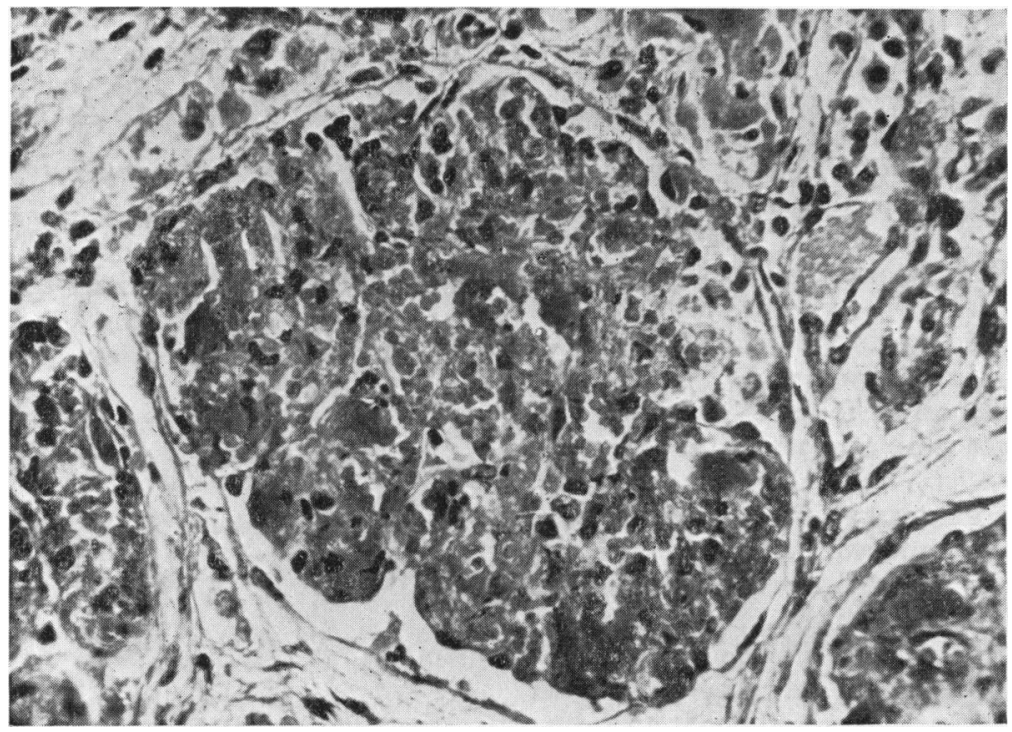

FIG. 1.-Case 1. A swollen haemorrhagic glomerulus with hyaline intracapillary thromboses. (Haematoxylin and eosin. $\times$ 490.)

eosinophilic thrombi were prominent in the capillary lumina of the glomerular tufts (Fig. 1) and in small arterioles (Fig. 2). Material of a similar appearance could also be demonstrated on basement membranes. This hyaline material gave the histochemical reactions of fibrin in its various stages of evolution (Lendrum et al., 1962). In Case 1 some glomeruli showed slight epithelial proliferation and a few crescents were seen.
In other organs there was evidence of a haemolytic process in both cases with haemosiderosis and extramedullary haemopoiesis in the liver and spleen, and erythroid hyperplasia of the bone-marrow. Megakaryocytes were plentiful. There was nothing to indicate an inflammatory process in either case and the vascular lesions were confined to the kidneys. No evidence of systemic xanthomatosis was seen.

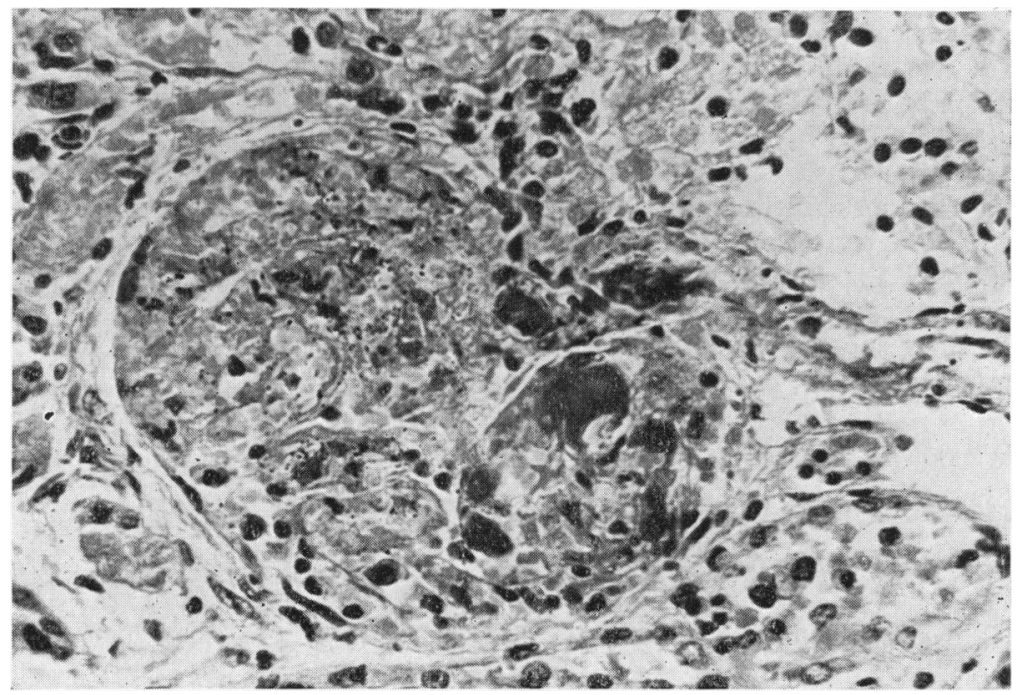

FIG. 2.-Case 2. A partly necrotic glomerulus with fibrinous thrombosis of afferent arteriole running across the photograph at 3 o'clock. (Martius, scarlet, blue. $\times 490$.) 


\section{Discussion}

These two cases illustrate the salient features of the haemolytic-uraemic syndrome. Both had severe haemolytic anaemia with bizarre red cells for which the term 'micro-angiopathic haemolytic anaemia' has been coined and which occurs in many other situations (Brain, Dacie, and Hourihane, 1962). It may well be assumed that the pathological basis for this is the particular form of fibrinous thrombotic vasculosis of renal capillaries and arterioles that was a prominent feature in both cases and was responsible for renal failure. This finding is similar to those reported by many others (Piel and Phibbs, 1966), though terminology varies. It is of interest to note that these pathological changes can be reproduced in the experimental Shwartzman reaction (McKay and Shapiro, 1958) and that their development can be prevented by the administration of heparin (Brain and Hourihane, 1967). Severe thrombocytopenia was only found in Case 1. This was formerly thought to be an essential feature (Javett and Senior, 1962), but from further reports it now appears that this is not necessarily so (McLean et al., 1966).

A familial occurrence is distinctly rare and is not mentioned in several recent reviews. Campbell and Carré (1965) drew attention for the first time to an association between the haemolytic-uraemic syndrome and idiopathic hyperlipaemia. In our cases the milky serum characteristic of hyperlipaemia was not seen, and extensive post-mortem histology showed no evidence of systemic xanthomatosis. The recent report by Hagge et al. (1967) prompted an extensive search of the literature, but we could only find one more report of a familial incidence of what might now be accepted as cases of this syndrome (Fison, 1956), this bringing the total number to 8 so far. Occurrence in the neonatal period raises the possibility of transplacental immunity, but, in the other cases referred to above, the syndrome developed 5 to 8 months after birth. It is difficult to conceive of a maternal antibody becoming operative after such an interval.

The aetiology remains obscure but it may well be that, despite its constant clinical pattern and uniform pathology, the condition has a multiple aetiology in which environmental, as well as genetic, factors play a part.

\section{Summary}

Two cases of the haemolytic-uraemic syndrome in sibs are reported, bringing the total in the world literature to 8. In both cases the onset was in the first month of life. Attempts to unravel the aetiology of this condition have concentrated, so far unsuccessfully, on environmental factors. It is suggested that some form of genetic predisposition may also have to be considered.

We are much indebted to Dr. R. A. B. Drury and Dr. J. Sakula for their advice and encouragement. We thank Miss D. Taylor for secretarial assistance.

\section{REFERENCES}

Brain, M. C., Dacie, J. V., and Hourihane, D. O'B. (1962). Microangiopathic haemolytic anaemia: the possible role of vascular lesions in pathogenesis. Brit. F. Haemat., 8, 358.

- and Hourihane, D. O'B. (1967). Microangiopathic haemolytic anaemia: the occurrence of haemolysis in experimentally produced vascular disease. ibid., 13, 135.

Campbell, S., and Carré, I. J. (1965). Fatal haemolytic uraemic syndrome and idiopathic hyperlipaemia in monozygotic twins. Arch. Dis. Childh., 40, 654.

Fison, T. N. (1956). Acute glomerulonephritis in infancy. ibid., 31, 101.

Gasser, C., Gautier, E., Steck, A., Siebenmann, R. E., and Oechslin, R. (1955). Hämolytisch-urämische Syndrome: bilaterale Nierenrindennekrosen bei akuten erworbenen hämolytischen Anämien. Schweiz. med. Wschr., 85, 905.

Gianantonio, C., Vitacco, M., Mendilaharzu, F., Rutty, A., and Mendilaharzu, J. (1964). The hemolytic-uremic syndrome. 7. Pediat., 64, 478 .

Hagge, W. W., Holley, K. E., Burke, E. C., and Stickler, G. B. (1967). Hemolytic-uremic syndrome in two siblings. New Engl. $\mathcal{F}$. Med., 277, 138.

Javett, S. N., and Senior, B. (1962). Syndrome of hemolysis, thrombopenia, and nephropathy in infancy. Pediatrics, 29, 209.

Lendrum, A. C., Fraser, D. S., Slidders, W., and Henderson, R. (1962). Studies on the character and staining of fibrin. $f$. clin. Path., 15, 401.

McKay, D. G., and Shapiro, S. S. (1958). Alterations in the blood coagulation system induced by bacterial endotoxin. f. exp. Med., 107, 353.

McLean, M. M., Jones, C. H., and Sutherland, D. A. (1966). Haemolytic-uraemic syndrome. A report of an outbreak. Arch. Dis. Childh., 41, 76.

Piel, C. F., and Phibbs, R. H. (1966). The hemolytic-uremic syndrome. Pediat. Clin. N. Amer., 13, 295. 